de kant van de Aufklärung geëngageerd, maar dan van een Aufklärung die de lotgevallen van de verdeelde rede, beter dan om het even welke filosofie of menswetenschap, mee heeft gemaakt"(blz. 52). Zelfs wanneer Beatrice de Gelder, in 'De achterkant van de rede' slechts heel zijdelings ingaat op wat Assoun schrijft ("Freud lijkt al even onbekwaam als Kant om iets te zeggen over de toepassingsvoorwaarden van zijn analyse"), dan nog daagt ze de lezer meer dan anderen uit tot het herlezen van de bijdrage die ze aanvalt. De leesbaarheid van Assouns bijdrage zal waarschijnlijk wel gedeeltelijk meebepaald worden door het eigen statuut van de psychoanalyse. Deze blijft immers doorheen haar hele geschiedenis de psychoanalyse-van-Freud waarbij de naamsbepaling een fundamenteel ander statuut heeft dan bij het getal van Avogadro of de relativiteitstheorie van Einstein. De dreiging puur inventariërend en bijgevolg encyclopedisch te werken is hierbij minder groot. En die indruk overheerst bij lectuur van het hele werk : de boeiendste opstellen zijn de opstellen die een vergelijkbare soberheid bewaren : De Dijn, 'natuur en redelijkheid' en Dillman/van Leeuwen, 'De redelijkheid van de ziekte' zijn bijvoorbeeld bijdragen die ik graag met studenten zou lezen.

Het moeilijke bij de benadering van een werk als In alle redelijkheid is de 'openheid' ervan : 'standpunten...' luidt de ondertitel en nergens staat dat de benadering volledigheid nastreeft. Deze ervaring alleen al is voor mijn zoekende student verrijkend. Of hij uiteindelijk in staat zal zijn de vraag naar de betekenis van de redelijkheid te beantwoorden zou ik maar durven beoordelen nadat ik de bundel, bijvoorbeeld als materiaal zou gehanteerd hebben bij een cursus over 'redelijkheid'. Mijn twijfel blijft groot.

Naast de reeds vermelde bijdrage bevat de bundel nog opstellen van N.H. Frijda en H.J. Pott ('Redelijkheid en emoties'), F. Droste ('Redelijkheid en cognitie'), R. Pinxten en D. Douchy ('Redelijkheid en cultuur'), C. Steel ('Verstandigheid en moraal'), G.M. van Asperen ('Redelijkheid en ethiek'), J.M. Broekman('Recht en redelijkheid'), F. van Eemeren en R. Grootendorst ('Redelijkheid in discussie') en D. Franck ('De redelijkheid van het gesprek').

Herman NOTE

\title{
HET PROBLEEM VAN DE DEMOCRATIE
}

Ludwig Heyde \& Ken Visser (red.), Filosofie en Democratie. Tilburg, Tilburg University Press, 1990, VIII + 229 blz., ISBN 9036197228

Ter gelegenheid van het tweede lustrum van de Faculteit der Wijsbegeerte van de Katholieke Universiteit Brabant verscheen onlangs een bundel filosofische essays over de democratie. Daarin heeft een groep van twaalf Tilburgse filosofen gepoogd de verhouding van democratie en rationaliteit, alsmede de specifieke aard van het politieke te begrijpen. Het bedoelt op de eerste plaats een pluralistisch boek te zijn, niet in het minst omdat ook onze moderne cultuur - als het milieu van de Westeuropese democratie - zich kenmerkt door pluralisme. Kaleidoscopisch mag dit boek gerust heten, 
want de invalshoeken waaronder men de democratie hier onder de loupe neemt, zijn niet gering. Dit blijkt niet enkel uit de vrij sterke heterogeniteit van 'recente beschavingsfeiten' die hier de aandacht krijgen, maar vooral ook uit het feit dat vanaf Plato tot heden zowat de meest markante (politieke en rechts-)filosofen, die over dit onderwerp hebben geschreven, aan bod komen. Dit moge blijken uit volgend overzicht van de hier geboden studies.

Het openingsartikel van E. Berns analyseert de politieke dimensie van Heideggers techniekopvatting Als historische dimensie van ons bestaan heeft de techniek een zekere prioriteit op de mens : niet de mens, maar de techniek beschikt. Maar juist in de techniek wordt de subjectiviteit tot haar uiterste gebracht : "als beschikker over middelen komt hij alleen in aanmerking om over zichzelf te beschikken". Deze soevereine mens, zegt Heidegger, is nu precies de burger van de democratische samenleving. Als "antwoord op problemen van onze technische samenleving in termen van de techniek" biedt democratie dan ook geen uitkomst tegenover het 'grootste gevaar', namelijk de uiterste moeilijkheid zich van de techniek af te wenden. Op twee punten wordt Heideggers opvatting over de verhouding tussen techniek en democratie nader uitgewerkt en in verband gebracht met zijn nationaal-socialistisch engagement. Enerzijds is er de planetaire expansiezucht en het geweld van de techniek, de universele heerschappij van Nietzsches (nihilistische) wil tot macht, waarin nazi-Duitsland (tot 1945 het zogenaamde 'rijk van het midden') een uitzonderingspositie zou innemen. Anderzijds brengt Heidegger de techniek in verband met de Griekse technè (een poëtisch-onthullend vervaardigen), waardoor hij het wezen van de techniek verbindt met kunst, en dit wezen radicaal onderscheidt van de techniek zelf. "Het verschil tussen de mens van de techniek en die van het wezen van de techniek is dat de eerste zelf beschikt en de tweede antwoordt op de beschikking". In dit antwoord is de mens passief tegenover het andere. Deze 'gelatenheid' of openheid voor de beschikking, dat tegelijk een afwending betekent van de soevereine mens als zelfbeschikker, wordt door Habermas afgewezen omdat de mens geheel ontslagen zou zijn van persoonlijke verantwoordelijkheid. Vandaar ook Habermas' terugkeer naar een autonomie van het subject in de zuiverheid van de communicatie. Tenslotte gaat Berns in op Derrida's antwoord, dat juist omwille van de verantwoordelijkheid (en in het spoor van Heidegger) veel verder gaat : "Ik kan met alles rekening willen houden, maar de berekening kan niet slagen, omdat het singuliere, dat mij er toe verbindt om er rekening mee te houden (daarom moet ik met alles rekening houden en vergt deconstructie een maximum aan rationaliteit), zich niet laat berekenen. Daarom is het een zaak van verantwoordelijkheid. Als men zijn verantwoordelijkheid heeft te nemen dan is dat juist omdat zich niet alles op grond van berekening laat voorzien".

F. van Peperstraten gaat in op de filosofische verantwoording van een politiek pluralisme in 'Het postmoderne denken van J.-F. Lyotard'. Tegenover Habermas' esthetica van het schone en zijn idee van een overkoepelende communicatieve praktijk, als een nostalgisch verlangen naar een indifferente totaliteit (waarvoor "de prijs van de terreur moet betaald worden"), ontwikkelt Lyotard het thema van de differentie vanuit een taalfilosofische beschouwing van de 'zin als gebeurtenis' (Ereignis), waardoor individuen gesitueerd worden. Niet in het speculatieve discours van de metafysica, maar binnen de heterogeniteit van het taalgebeuren zelf - een heterogeniteit van regimes (beschrijven, bevelen, vragen, ...) en genres (finaliteit van strategieën of wijzen van aanknoping) - wordt de maatschappelijke werkelijkheid correct beschreven. Lyotard stelt zich tot taak een "filosofische politiek in te stellen, door te laten zien dat de aanknoping van de ene zin bij de andere problematisch is". Deze 'dreiging van het geschil' is nu de toestand van de politiek. In tegenstelling tot de heerschappij van de narratie (zoals 
bijvoorbeeld onder het nazisme), waarin het geschil uit deze wereld wordt verdrongen ("we moeten slechts zijn wat 'wij' altijd al waren"), kunnen in de democratische beraadslaging principieel verschillende genres worden beproefd. De 'eenheid' van deze 'deliberatieve ordening' wordt tot stand gebracht door zich te onderwerpen aan de vraag : "Wat moeten wij zijn ?". Echter, "de verplichting kan geen universele geschiedenis verwekken" (Kant, Hegel, Marx). Tegenover deze 'obsessie van de totaliteit' stelt Lyotard zich de vraag "welke de beste gemeenschap is en hoe deze zich laat verwerkelijken ?". De inzet hierbij blijft het ter sprake komen van het geschil, wat "concreet de verdediging betekent van de mensenrechten, in het bijzonder van de vrije meningsuiting en van de hieraan verbonden deliberatieve ordening".

B. van Roermund interpreteert de geschriften over democratie van de Oostenrijkse jurist Hans Kelsen, waarin hij vooral aandacht besteedt aan de betekenis van het begrip vertegenwoordiging. De analyse daarvan wordt verder toegespitst op de controverse tussen Kelsen en de Duitse jurist Carl Schmitt (tijdens de jaren twintig en de vroege jaren dertig in de Weimarrepubliek). Eén der fundamentele problemen in deze polemiek draait rond het aanwijzen van de 'hoogste macht' in de samenleving, meer in het bijzonder rond de bescherming van de constitutie als uiteindelijke geldingsgrond van de rechtsorde. Kan volgens Kelsen de bescherming van de grondwet (als gestelde hoogste norm) zeer goed worden toevertrouwd aan een constitutioneel hof, volgens Schmitt is het staatshoofd - die als drager van een neutrale macht buiten de strijd van parlement en ministerraad staat en als zodanig ook beslist over de uitzonderingstoestand - de enige die de grondwettelijkheid der wetten kan beschermen (bij Schmitt valt grondwet samen met de identiteit van een volk). Vooral Schmitts these die de zelflegitimatie van de staat via het beroep op de uitzonderingstoestand mogelijk maakt, neemt Kelsen op de korrel .

In 'Van de ene democratie naar de andere' bespreekt D. Loose de politieke filosofie van A. de Tocqueville en C. Lefort. Inzet van deze analyse is de dialectiek van vrijheid en gelijkheid als bij uitstek te bewaken opgave van de democratie. Met Lefort wordt gevraagd naar de democratische legitimatie van de politieke macht, die haar bestaansgrond vindt in de verantwoording van de vormgeving van de maatschappij, een vormgeving die op haar beurt er altijd een is van politieke aard. Verder wordt de eigen politieke aard van de democratie verhelderd door de logica van het totalitarisme te begrijpen. Uitvoerige tekstfragmenten van beide auteurs bedoelen onder andere volgende merkwaardige spanning - waarin de legitimatie van de politieke macht in de democratie besloten ligt - te verduidelijken : "de macht is van allen, maar ook van niemand". Het grote gevaar schuilt dan ook in "het risico dat een absolute macht zich van bovenuit opwerpt als tegemoetkomend aan het vacuum dat de democratie uit zichzelf achterlaat". Want in de democratie is de macht niet localiseerbaar (waarom democratie aan de macht voortdurend opnieuw een politieke gestalte moet geven). Hier dreigt overigens het gevaar van totalitarisme dat de 'lege plaats van de macht' steeds weigert. Anderzijds wordt getoond hoe de menselijke vrijheid zich haast vanzelf onttrekt aan de totale objectivering, waardoor totalitarisme niet geheel kan slagen. "De illusoire vereniging van de hele maatschappij zonder enige alteriteit of dissidentie is een zo hoog bod dat het totalitair regime er zich vanzelf door ruïneert".

In 'Politieke ethos en metafysiek' bevraagt A. Leijen de ontologische mogelijkheidsvoorwaarden van gelijkheid en vrijheid. Hij baseert zich op de sociologische waarneming van de Tocqueville dat in de moderne democratie een grotere maatschappelijke gelijkheid ten koste gaat van gelijkheid in het politieke handelen, en dat mensen dikwijls meer bekommerd zijn om hun bestaanszekerheid (gelijkheid van maatschappelij- 
ke condities) dan om hun politieke vrijheid. Nochtans is de ervaring van vrijheid een realiteit die onder ons niet is verdwenen. Aangetoond wordt dat deze vrijheidservaring haar mogelijkheidsvoorwaarde heeft in een ontologische positie van de zijnsmetafysiek (in tegenstelling tot de metafysiek van de subjectiviteit, waarin de moderne subjectiviteit als 'ontgrensde vrijheid' tot volledige heerschappij is gekomen over natuur en cultuur, zie Heidegger). Dit laat de auteur toe terug te keren naar de filosofie van Aristoteles. Het grootste gedeelte van de uiteenzetting is gewijd aan de elementaire metafysische uitgangspunten van Aristoteles, want hier affirmeert de auteur heel sterk onze eindige vrijheid.

In 'Res Publica Res Populi' gaat T. Rieter in op de staatsdefinities van Cicero en Augustinus, waarbij hun teksten zelf (resp. 'De re publica' en 'De civitate Dei') strikt gevolgd worden. Cicero verwerpt monarchie, aristocratie en democratie ten gunste van een 'gemengde constitutie' die hij als de beste staatsvorm beschouwt, die in de Romeinse Republiek ook werkelijkheid is geworden. Dit laatste wordt nu ten stelligste door Augustinus verworpen, omdat volgens hem echte rechtvaardigheid uitsluitend te vinden is in een door Christus gestichte en bestuurde staat. De auteur wijst op het belang van de confrontatie van beide interpretaties, omwille van de wederzijdse aanstoot of mogelijke verzoening tussen een christelijke en niet-christelijke bestaansuitleg.

In 'De achterkant van de democratie' geeft B. de Gelder een overzicht van een aantal psychologische onderzoeksresultaten die het (rationalistische) ideaal is van de menselijke redelijkheid en die in het bijzonder de illusie van de almacht van de mens als rationele beslisser, sterk relativeren. Aangetoond wordt hoe het begrippenarsenaal van de traditionele psychologie een cruciale rol blijft spelen in de toepassing van ethische principes in het dagelijkse leven, een spanningsveld zonder hetwelk onze bekwaamheid concreet democratisch te handelen geen gestalte zou krijgen.

In 'Rationele wetenschapsontwikkeling in een pluralistische democratie' bespreekt B. Hamminga de ontwikkeling van Jaargangenmodellen voor Nederland door het Centraal Planbureau en anderen in de jaren zeventig, bij wijze van voorbeeld van ontwikkeling van economische theorie in relatie tot de maatschappelijke discussie over de ruimte voor loonsverhoging.

In 'Mogelijkheden en grenzen van een procedurele opvatting van democratie' bespreekt $\mathrm{H}$. van Erp twee varianten van de economische opvatting van democratie : de democratie als sociale keuzeprocedure (principiële beslisbaarheid over alle zaken in de samenleving door eenvoudige vaststelling van stemverhoudingen), en de democratie van het competitief leiderschap (politiek als spel om de macht). Getoond wordt hoe in beide opvattingen het accent ligt op de procedurele kanten van democratische besluitvorming, waarbij de beoordeling van de inhoud van de besluiten geheel buiten beschouwing blijven. In een louter pragmatische beoordeling van de democratie (democratie als louter instrumentele procedure), raakt de idee van de democratie als rechtvaardigingsgrond van de staatsmacht echter op de achtergrond. Vraag is dan ook of het louter reduceren van democratische procedures tot zuiver pragmatische methoden van collectieve besluitvorming niet het symptoom blijft van een totalitaire tendens in onze samenleving. De auteur betoogt dat een zuiver procedurele opvatting onhoudbaar is, omdat het de ontkenning is van het politieke karakter van het collectieve besluitvormingsproces. De geldigheid van democratische procedures dient gebaseerd in een politiek ideaal van een democratische samenleving, waarvan de waarde op haar beurt gefundeerd is in de ideeën van vrijheid en gelijkheid.

T. Storcken gaat in op de 'Gewenste eigenschappen voor democratische beslissingsprocedures'. Hij bespreekt twee soorten 'gelijkheids'-principes - namelijk dat 
van gelijke behandeling van de personen en dat van gelijke behandeling van de mogelijke beslissingen waartoe de procedure kan leiden - welke democratische beslissingsprocedures nastreven, maar moeilijk tegelijkertijd te realiseren zijn. Gebruik makend van een formeel model toont de auteur dat een beslissingsprocedure in het algemeen niet aan beide soorten gelijkheidsprincipes kan voldoen.

Aan de hand van een combinatie van de ideeën van Grelling, Menger en Hahn vraagt $H$. Visser ('Logisch-empirisme en democratie') naar een instrumentarium voor de logische analyse van systemen van redeneringen met waarde-oordelen waarmee rationele discussie over zulke oordelen in het algemeen, en over democratie in het bijzonder zou mogelijk worden. Visser waagt zich aan een begripsprecisie of 'rationele reconstructie' van de notie democratie, waarbij de karakteriseringen van resp. Schumpeter en Reichenbach model staan.

In de laatste bijdrage 'Democratie en waarheid' onderzoekt L. Heyde in welke mate het denken van Plato en Hegel kan bijdragen tot een objectief en gefundeerd inzicht in de democratie. Zowel Plato als Hegel hebben - in naam van de waarheid - ernstige bezwaren tegen de democratie. Ondanks hun kritiek wijst Heyde op de onontbeerlijkheid van hun inzichten om de moderne parlementaire democratie te begrijpen. Voor Plato ligt de waarheid van de politiek niet in de factische wil, maar in de ideale vorm. De auteur toont dat de prioriteit van de algemeenheid als idealiteit op de feitelijkheid van de politiek een beslissende werking heeft gehad in de (Westerse) geschiedenis van de politieke filosofie. Hegel zal Plato aanvullen door de algemeenheid te bemiddelen met de subjectieve vrijheid in de bespreking van Hegels democratie- en staatsbegrip toont het artikel hoe onze parlementaire democratie medebepaald wordt door Hegels begrip van de moderne staat als de dialectische eenheid van recht en sociale rechtvaardigheid. Verder wordt er op gewezen hoe maatgevend deze 'denkers van de algemeenheid' blijven, zeker in een tijd waarin het algemene verwordt tot louter instrument van de bijzonderheid (economisme, hedonisme, technicisme). Tot slot krijgen we een belichting de actualisering van de problematiek van de bemiddeling, zoals deze opnieuw op de voorgrond treedt in het vraagstuk van de Europese eenwording.

Democratie is een begrip dat wij, Westeuropeanen, nogal gemakkelijk in de mond nemen; dit neemt niet weg, zoals bovenstaande studies aantonen, dat de betekenis ervan in de meest verschillende disciplines en op alle denkbare niveaus bestendig ter discussie staat. Is voor ons de rechtsstaat slechts bestaanbaar als democratie, waarin de vrijheid "altijd dat is wat in de politiek in het geding is", toch belet dit niet dat we bijna dagelijks kunnen waarnemen hoe het juist beleidsverantwoordelijken zijn die de democratische besluitvorming bagatelliseren. Daarom lijkt meer dan ooit wat de Tocqueville honderdvijftig jaar geleden schreef over democratische volkeren. : "dat ze wel van de macht houden, maar niettemin geneigd zijn degenen die hem uitoefenen te minachten en te haten. Ze ontsnappen er ook aan omdat hun onbeduidendheid en hun wispelturigheid hen redt". Nochtans is democratie geen zaak van wispelturigheid, maar verdient ze veel aandacht en blijvende belangstelling. Daarom kan een boek over democratie nooit een overbodige luxe zijn. 